\title{
Bacterial shoot blight caused by Pseudomonas cerasi, a new pathogen of pear tree
}

\author{
Okhee $\mathrm{Choi}^{1} \cdot$ Byeongsam Kang $^{2} \cdot$ Yeyeong Lee $^{3} \cdot$ Seunghoe Kim $^{3} \cdot$ Jonghee Oh $^{4} \cdot \mathrm{Hongsup} \mathrm{Kim}^{4} \cdot \mathrm{Jinwoo} \mathrm{Kim}^{1,2,3}$ (D)
}

Received: 19 March 2020 / Accepted: 29 May 2020 / Published online: 3 June 2020

(C) Australasian Plant Pathology Society Inc. 2020

\begin{abstract}
In 2018, bacterial shoot blight was observed on Asian pear trees (Pyrus pyrifolia) in an orchard in Jinju, South Korea. The young pear shoots were infected and showed shoot blight symptoms: the shoot tips shriveled and turned tan in color, and this spread from the shoot tip down the stem and into the leaves. The causal pathogen was isolated from the diseased lesions and identified as Pseudomonas cerasi based on API tests and multilocus sequence analysis (MLSA) using the $16 \mathrm{~S}$ rRNA, gyrB, rpoB, and rpoD gene sequences. The symptoms after artificial inoculation were identical to natural field symptoms, whereas negative control plants were asymptomatic. Bacteria were re-isolated from the artificially induced lesions on blossoms and shoots, and their identity was confirmed by rpoD sequencing. This is the first report of bacterial shoot blight on pear tree caused by Pseudomonas cerasi Griffin in the world.
\end{abstract}

Keywords Bacterial shoot blight $\cdot$ Pear $\cdot$ Pseudomonas cerasi $\cdot$ Multilocus sequence analysis

The consumption of pears in Korea is decreasing as the number of single-member households increases. Moreover, many young Koreans only consume pears on traditional Korean holidays, such as Korean Thanksgiving and Lunar New Year's Day (USDA GAIN report 2018; www.gain.fas.usda. gov). The patterns of pear consumption in Korea are changing with pears now used more as a food sweetener than as a raw material, and as a health supplement in the form of hot pressed juice. Korea produces about 265,757 metric tons of pears per year on 10,861 ha. In the past decade, the area of planted pears has steadily decreased by about $41 \%$ (Korean Statistical Information Service 2018; www.kosis.kr.eng). Nevertheless, pears are still a popular fruit in Korea.

Okhee Choi and Byeongsam Kang contributed equally to this work.

Jinwoo Kim

jinwoo@gnu.ac.kr

1 Institute of Agriculture and Life Science, Gyeongsang National University, Jinju 52828, South Korea

2 Division of Applied Life Science, Gyeongsang National University, Jinju, South Korea

3 Department of Plant Medicine, Gyeongsang National University, Jinju, South Korea

4 Seed Testing and Research Center, Korea Seed and Variety Service, Gimcheon 39660, South Korea
In 2018, bacterial shoot blight was observed on Asian pear trees (Pyrus pyrifolia; cv. Singo) in an orchard in Jinju, South Korea. It occurred in pear trees planted in orchards and along roads and 5\% of the branches per infected tree were diseased. Young infected pear shoots exhibited shoot blight symptoms: the shoot tips shriveled and became tan colored, and this spread from the shoot tip down the stem and into the leaves (Fig. 1).

Pear shoots with blight were collected from an orchard in Jinju, South Korea. Bacteria were isolated from diseased lesions according to the protocol set out by Choi et al. (2017). Briefly, small pieces $(3 \times 3 \mathrm{~mm})$ taken from the diseased shoot tissues were disinfested by placing them in $1 \%$ sodium hypochlorite solution for $30 \mathrm{~s}$, washing twice in sterile distilled water, and transferring to $1.5-\mathrm{ml}$ microtubes containing $0.5 \mathrm{ml}$ sterile distilled water. The tissues were macerated with a sterile tip to make a suspension. A 100- $\mu$ l aliquot of the suspension was spread on $1 / 10$ tryptic soy broth agar (TSBA) and incubated at $28{ }^{\circ} \mathrm{C}$ for 2 days. Gram-negative, non-spore forming, rod-shaped pseudomonads were consistently recovered from diseased twigs exhibiting blight symptoms. Two bacterial colonies identical in appearance were selected for testing hypersensitive reactions on tobacco leaf. The two isolates (MHGNU B107a-b) exhibited opaque, circular, raised colonies with entire margins on TSBA, and produced a hypersensitive reaction on a tobacco leaf. A representative isolate $\mathrm{MHGNU} \mathrm{B} 107 \mathrm{a}$ was deposited in the Korean Agricultural Culture Collection (KACC 21449). 
Fig. 1 Bacterial shoot blight caused by Pseudomonas cerasi on pear. a Bacterial shoot blight; b Enlarged image
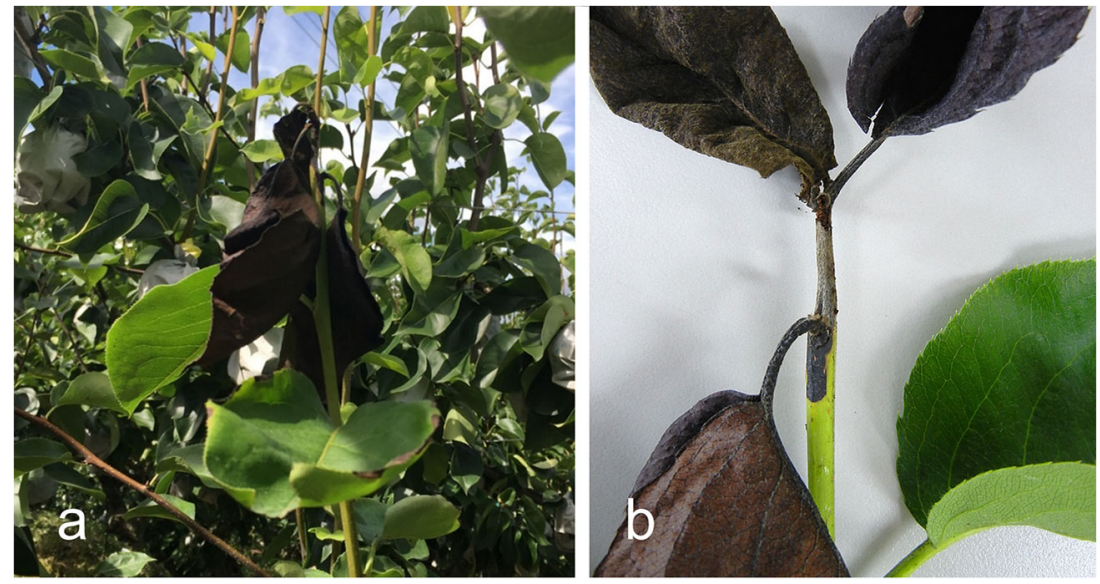

The two isolates, MHGNU B107a-b, were subjected to pathogenicity tests on pear flowers and young shoots (cv. Singo) of trees growing in pots. A bacterial suspension $\left(10^{8} \mathrm{CFU} / \mathrm{ml}\right)$ was sprayed on the flowers on a twig and infiltrated into another three young shoots. The inoculated pear flowers and shoots were covered with transparent plastic bags for 2 days. After removing the plastic bags, the pear plants were placed in a plant growth chamber at $25{ }^{\circ} \mathrm{C}$ and $90 \%$ humidity with a 12 -h light $\left(150 \mu\right.$ moles $\left./ \mathrm{m}^{2} / \mathrm{s}\right)$. Sterile distilled water was used as a negative control. The two isolates, MHGNU B107a-b, produced blossom and shoot blight symptoms that were identical to the symptoms observed in the field (Fig. 2a), and there was no difference between the isolates. The negative control inoculated with water showed no symptoms (Fig. 2b). Bacteria were re-isolated from the inoculated lesions and confirmed by $r p o D$ gene sequencing to satisfy Koch's postulates.

To confirm the identity, the partial 16S rRNA region and $r p o D$ gene were amplified and sequenced. PCR amplification was performed with primer pairs; $27 \mathrm{mF}\left(5^{\prime}-\mathrm{AGAG}\right.$ TTTGATCMTGGCTCAG-3') and 1492mR (5' GGYTACCTTGTTACGACTT-3') for the partial 16S rRNA region; PsEG30F (5'-ATYGAAATCGCCAARCG-3') and PsEG790R (5'-CGGTTGATKTCCTTGA-3') for the rpoD gene (Mulet et al. 2009); UP-1E (5'-CAGGAAAC AGCTATGACCAYGSNGGNGGNAARTTYRA-3') and A P r U ( $5^{\prime}$ - T G T A A A A C G A C G G C C A G T G C NGGRTCYTTYTCYTGRCA-3') for the $g y r B$ gene (Ait Tayeb et al. 2005); and LAPSs (5'-TGGCCGAGAACCAG TTCCGCGT-3') and LAPs27 (5'-CGGCTTCGTCCAGC TTGTTCAG-3') for the $r p o B$ gene (Hall et al. 2016). DNA extraction and PCR amplification were conducted as described previously (Choi et al. 2016). PCR was performed on a thermal cycler (T100; Bio-Rad, Hercules, CA, USA) using PCR premix (Bioneer, Daejeon, Korea), $1 \mu \mathrm{g}$ of genomic DNA, and $1 \mathrm{mM}$ of each primer: at $98^{\circ} \mathrm{C}$ for $2 \mathrm{~min}, 30$ cycles of $98^{\circ} \mathrm{C}$ for $30 \mathrm{~s}$, $55^{\circ} \mathrm{C}$ for $30 \mathrm{~s}$, and $70{ }^{\circ} \mathrm{C}$ for $1 \mathrm{~min}$, and a final 4-min extension at $72{ }^{\circ} \mathrm{C}$. The PCR products were examined by electrophoresis in $0.8 \%$ agarose gels, purified using Expin Gel SV (GeneAll Biotechnology, Seoul, Korea), and sequenced with the same primer pairs used for PCR amplification at Macrogen (Daejoen, South Korea). The GenBank accession numbers for the partial $16 \mathrm{~S}$ rRNA, $r p o D$, gyrB and $r p o B$ gene sequences of strain MHGNU B107a are: MK779199, MK779202, MN061942 and MN061943, respectively. The DNA sequences were analyzed using the BLAST program and compared with the NCBI/GenBank database (http:/www.ncbi.nlm.nih.gov/ blast/). Based on an analysis of $16 \mathrm{~S}$ rDNA sequences the isolates shared the highest similarity (over 99.8\%) with Pseudomonas tremae CFBP 6111(T) and P. cerasi 58(T).

Phylogenetic analysis using multilocus sequence analysis (MLSA) and comparison with sequences in the PADMB database (http://genome.ppws.vt.edu/cgi-bin/MLST/home.pl) was performed according to a previously reported method (Mulet et al. 2010). Phylogenetic analysis based on MLSA using the $16 \mathrm{~S}$ rRNA, gyr $B, r p o B$ and $r p o D$ gene sequences was performed using the Neighbor-joining method and Tajima-Nei distance modeling in MEGA 7.0 (Kumar et al. 2016). The sequences of related pseudomonads were downloaded from GenBank. In the phylogeny based on MLSA using the $16 \mathrm{~S}$ rRNA, gyrB, $r p o B$ and $r p o D$ gene sequences, MHGNU B107a and MHGNU B107b clustered in the same group as P. cerasi (Fig. 3).

Bacteria exhibiting virulence on pear plants were subjected to biochemical analysis using the Analytical Profile Index (API) system (BioMérieux, Marcy l'Étoile, France), according to the supplier's instructions. The API 20NE tests revealed that MHGNU B107a and MHGNU B107b utilized D-glucose, L-arabinose, D-mannose, D-mannitol, potassium gluconate, capric acid, malic acid, and trisodium citrate, but that both isolates did not utilize $\mathrm{N}$-acetyl-glucosamine, D-maltose, adipic acid, or phenylacetic acid. Both isolates were positive for $\beta$-glucosidase and oxidase but were negative for the production of indole, arginine dihydrolase, urease, $\beta$-galactosidase, protease, and potato tube rot. Nitrate was not reduced to nitrite. 

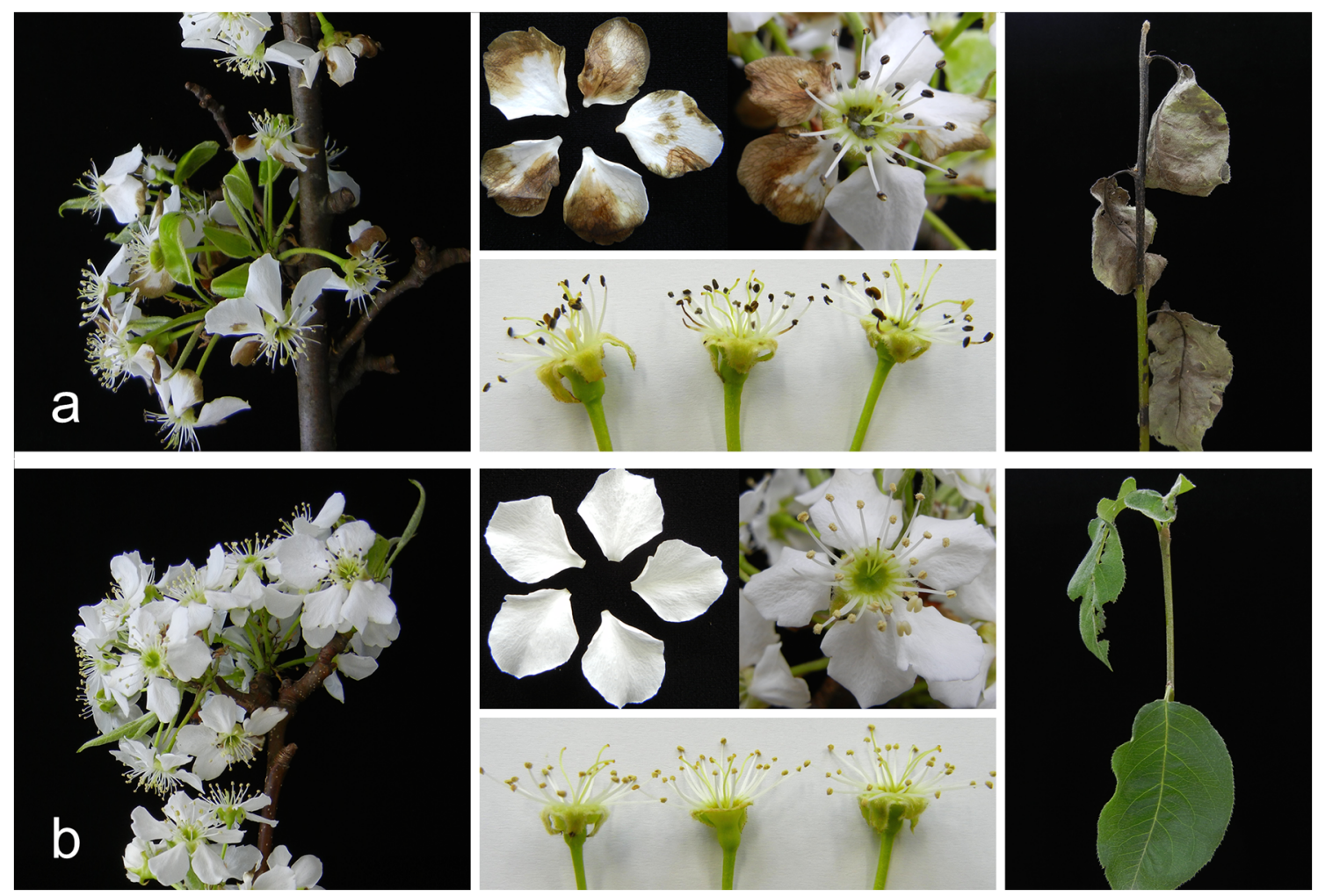

Fig. 2 Pathogenicity of Pseudomonas cerasi causing bacterial shoot blight on pear. a Blossom and shoot blight symptoms induced artificially by P. cerasi MHGNU B107a inoculation: blight of blossoms, petals, and shoots, and discoloration of the anther; b negative control with no symptoms

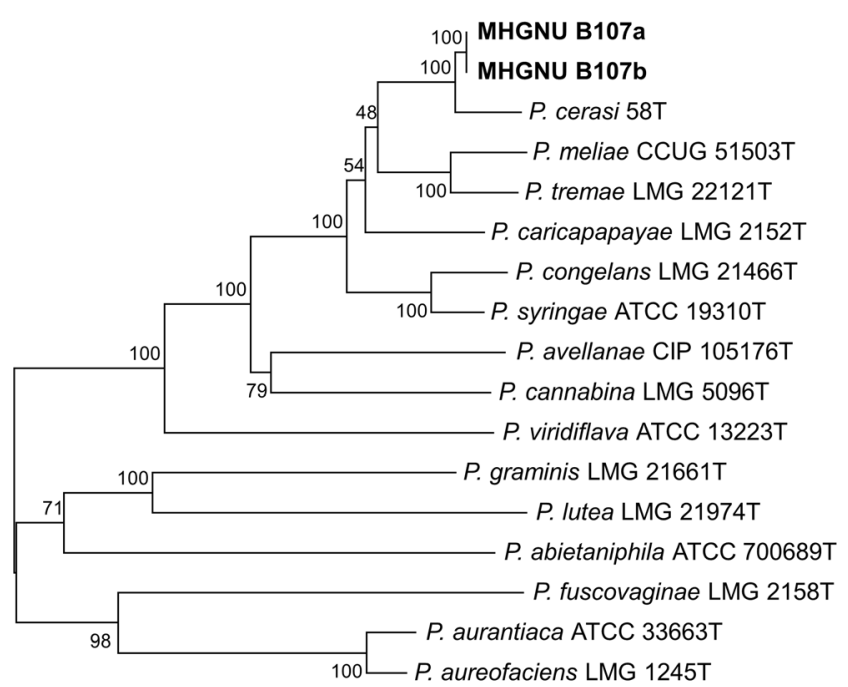

0.01

Fig. 3 Phylogenetic tree of Pseudomonas strains based on the phylogenetic analysis of four concatenated genes (16S rRNA, gyrB, $r p o B$, and $r p o D$ ). Distance matrices were calculated by the JukesCantor method and are in the units of number of base substitutions per site. Dendrograms were generated by Neighbor-Joining. Numbers above the branches are the bootstrap values. Bars indicate the number of nucleotide substitutions per site. The isolates obtained in this study is in bold. Evolutionary analyses were conducted in MEGA7
Based on pathogenicity, biochemical tests and multilocus sequence analysis (MLSA) using the $16 \mathrm{~S}$ rRNA, gyrB, rpoB, and $r p o D$ gene sequences, the causal bacterium was identified as Pseudomonas cerasi. The disease caused by $P$. cerasi was first discovered in Polish cherry trees with flower dieback and necrotic spots on shoots, leaves and fruits (Kałużna et al. 2016). This is the first report of bacterial shoot blight on pear tree in the world. It is not known how this bacterial pathogen was introduced to the orchard Jinju. However, bacterial blight caused by $P$. syringae pv. syringae has been reported in Korea on apples (Seo et al. 1999; Cheon and Jeon 2015) and kiwifruit (Shin et al. 2004; Kim et al. 2017). The recent outbreak of this disease indicates that the bacterial species affects the fruiting of pear and poses a possible threat to pear cultivation and production in Korea.

Acknowledgements This research was supported by a fund by Research of Animal and Plant Quarantine Agency, South Korea.

\section{References}

Ait Tayeb L, Ageron E, Grimont F, Grimont PA (2005) Molecular phylogeny of the genus Pseudomonas based on rpoB sequences and application for the identification of isolates. Res Microbiol 156: 763-773 
Cheon W, Jeon Y (2015) Survey of major diseases occurred on apple in northern Gyeongbuk from 2013 to 2014. Res Plant Dis 21:261-267

Choi O, Kang B, Cho SK, Park J, Lee Y, Kim W-I, Kim J (2016) First report of Pseudomonas syringae pv. syringae causing bacterial leaf blight on Miscanthus $\times$ giganteus. J Plant Dis Prot 123:137-140

Choi O, Kang B, Cho SK, Park J, Lee Y, Kim W-I, Marunga J, Hwang I, Kim J (2017) Identification of Pseudomonas syringae pv. syringae causing bacterial leaf blight of Miscanthus sinensis. J Plant Dis Prot 124:97-100

Hall SJ, Dry IB, Blanchard CL, Whitelaw-Weckert MA (2016) Phylogenetic relationships of Pseudomonas syringae pv. syringae isolates associated with bacterial inflorescence rot in grapevine. Plant Dis 100:607-616

Kałużna M, Willems A, Pothier JF, Ruinelli M, Sobiczewski P, Puławska J (2016) Pseudomonas cerasi sp. nov. (non griffin, 1911) isolated from diseased tissue of cherry. Syst Appl Microbiol 39:370-377
Kim GH, Kim DR, Park S-Y, Lee YS, Jung JS, Koh YJ (2017) Incidence rates of major diseases of kiwiberry in 2015 and 2016. Plant Pathol J 33:434-439

Kumar S, Stecher G, Tamura K (2016) MEGA7: molecular evolutionary genetics analysis version 7.0 for bigger datasets. Mol Biol Evol 33: 1870-1874

Mulet M, Bennasar A, Lalucat J, García-Valdé E (2009) An rpoD-based PCR procedure for the identification of Pseudomonas species and for their detection in environmental samples. Mol Cell Probes 23: 140-147

Mulet M, Lalucat J, García-Valdés E (2010) DNA sequence-based analysis of the Pseudomonas species. Environ Microbiol 12:1513-1530

Seo ST, Won SY, Park DH, Kim YS, Hur JH, Lim CK (1999) Bacterial shoot blight of apple caused by Pseudomonas syringae. Res Plant Dis 5:46-49

Shin JS, Park JK, Kim GH, Park JY, Han HS, Jung JS, Hur JS, Koh YJ (2004) Identification and ecological characteristics of bacterial blossom blight pathogen of kiwifruit. Res Plant Dis 10:290-296 